\title{
HUBUNGAN KELUARGA SINGLE PARENT DENGAN KEMANDIRIAN BELAJAR SISWA DI SMA NEGERI 2 PADANGSIDIMPUAN
}

\author{
${ }^{1}$ Nor Mita Ika Saputri, ${ }^{2}$ Rahmad Huda, ${ }^{3}$ Sri Muliani Pulungan, ${ }^{4}$ Harun Arrasyd \\ Universitas Muhammadiyah Tapanuli Selatan \\ normitaikasaputri@um-tapsel.ac.id
}

\begin{abstract}
The problem that is often faced by single parent families is the problem of children. Single parent families are always focused on the problems they face and the weaknesses of losing their partners. In this condition, single parent families must be able to meet the psychological and psychological needs of the child so that there is no gap between the children in facing each of their developments. This study aims at the relationship of single parent families with the learning independence of students at SMA Negeri 2 Padangsidimpuan. This research uses quantitative methods. The population of this research is all students of SMA Negeri 2 Padangsidimpuan, amounting to 756 students consisting of three grade levels. The results showed that there was a significant relationship between single parent families and students' learning independence at SMA Negeri 2 Padangsidimpuan. The magnitude of the correlation between single parent families and independence was $41.3 \%$, while $58.7 \%$ was the magnitude of the correlation from other factors not examined in this study.
\end{abstract}

Keywords: Single parent family, independence, students

\begin{abstract}
Abstrak: Permasalahan yang sering dihadapi oleh keluarga single parent adalah masalah anak. Keluarga Single parent selalu terfokus pada masalah yang dihadapinya dan kelemahan dalam kehilangan pasangannya. Pada kondisi seperti ini keluarga single parent harus bisa memenuhi kebutuhan secara psikologis maupun psikis anak agar tidak terjadi kesenjangan anak dalam menghadapi setiap perkembangannya.Penelitian ini bertujuan hubungan keluarga single parent dengan kemandirian belajar siswa di SMA negeri 2 Padangsidimpuan. Penelitian ini menggunakan metode kuantitatif. Populasi penelitian ini yaitu seluruh seluruh siswa SMA Negeri 2 Padangsidimpuan yang berjumlah 756 siswa yang terdiri dari tiga tingkatan kelas. Hasil penelitian menunjukkan bahwa ada hubungan yang signifikan antara keluarga single parent dengan kemandirian belajar siswa di SMA Negeri 2 Padangsidimpuan. Besar korelasi antara keluarga single parent dengan kemandirian diperoleh sebesar 41,3\% sedangkan 58,7\% merupakan besar korelasi dari faktor lain yang tidak diteliti dalam penelitian ini.
\end{abstract}

Kata kunci: Keluarga single parent, kemandirian, siswa

\section{PENDAHULUAN}

Orang tua berperan penting dalam pendidikan dan penanaman karakter anak, begitu juga dalam hal menanamkan sikap kemandirian anak. Pendidikan yang pertama kali di dapatkan anak sebelum pendidikan formal disekolah adalah pendidikan dari keluarga yaitu di rumah, karena seorang anak terlahir ke dunia pertama kali dalam lingkungan keluarga dan didikan dari orang tua. Menurut M.

Djawad Dahlan dalam jurnal Stanislaus. S

(2010), fungsi dasar dari sebuah keluarga

adalah memberikan rasa memiliki, rasa aman,

kasih sayang dan mengembangkan hubungan

yang baik antara anggota keluarga. Hubungan

cinta kasih di dalam keluarga tidak hanya

sebatas perasaan, akan tetapi juga menyangkut

dengan pemeliharaan, rasa tanggung jawab, 

perhatian, pemahaman, respect dan keinginan untuk membesarkan anak yang dicintainya.

Menurut Berliana dalam jurnal Olatunde dan Abisola (2010) seorang ibu single parent memiliki kualitas komunikasi yang baik dibandingkan ayah yang berperan sebagai single parent. Single parent yang dijalankan seorang ayah lebih sulit dibandingkan dengan single parent seorang ibu. Dalam hal ini membuat anak-anak yang tinggal dengan ayah single parent tersebut menjadi tidak bisa dekat dan terbuka dengan ayah single parentnya, sedangkan seorang ibu yang single parent akan berusa untuk berkomunikasi dan mendekati anaknya ditengah-tengah pekerjaannya.

Pada kondisi seperti ini keluarga single parent harus bisa memenuhi kebutuhan secara psikologis maupun psikis anak agar tidak terjadi kesenjangan anak dalam menghadapi setiap perkembangannya. Berdasarkan hasil penelitian yang dilakukan oleh Kimmel 1998 dalam jurnal Listia Dewi keluarga single mother memiliki kesulitan di dalam berbagai bidang, terutama di dalam masalah merawat anak dan memenuhi ekonomi keluarga. Mereka umumnya tidak bisa membagi waktu antara mengurus anak dengan bekerja. Apabila lebih mementingkan pekerjaan, tentu saja mereka tidak memiliki waktu untuk merawat anak mereka. Sebaliknya, jika single mother sibuk merawat anaknya tentu saja keluarga tidak akan memiliki penghasilan karena tidak akan memiliki penghasilan karena tidak ada yang mencari nafkah.
Permasalahan yang sering terjadi juga masalah kenakalan remaja karena kurangnya mendapatkan perhatian dan pengawasan dari keluarga karena sibuk bekerja. Disekolah anakanak menjadi nakal dan tidak terkendali karena sering mencari-cari perhatian dari guru serta melakukan kenakalan-kenakalan lainnya. Masalah anak dalam kesulitan ekonomi membuat anak malas untuk pergi kesekolah dan merasa tidak percaya diri untuk berteman dengan kawan-kawannya.

Menurut Surya dalam jurnal Listia Dewi (2017) yang tertera dalam (Suwinta, Perbedaan Kemandirian remaja SMA antara yang single father dengan single mother akibat perceraian,2015) dalam menghadapi masalahmasalah keluarga single parent setiap orang tua mempunyai cara dan kiat yang berbeda antara satu dengan yang lainnya, tergantung dari kondisi yang dihadapi oleh masing-masing keluarga single parent. Bahkan ada keluarga yang single mother lebih sukses dibandingkan dengan keluarga yang utuh. Hal ini tentu saja tergantung pada pola asuh dan juga keterampilan sari seorang ibu untuk mengelola keluarganya dan memberikan motivasi serta dukungan penuh kepada anak-anaknya agar tidak gagal dan terjerumus kepada pergaulan yang salah.

Dari berbagai fenomena di atas, banyaknya terjadi permasalahan bagi keluarga single parent yang membuat masyarakat memberikan pandangan yang buruk terhadap single parent yang dianggap keluarga yang abnormal. Pada saat proses magang peneliti 
melihat ada beberapa siswa yang merupakan keluarga single parent tapi mempunyai sifat kemandirian belajar dan ada juga siswa yang berkeluarga single parent tapi sering membuat keributan disekolah. Dengan hal tersebut peneliti tertarik untuk melakukan penelitian mengenai bagaimana sikap siswa yang memiliki keluarga single parent dalam melakukan pendidikannya disekolah,bisakah siswa belajar lebih mandiri dari siswa-siswi lainnya yang memiliki keluarga yang utuh.

\section{METODE}

Metode penelitian ini menggunakan kuantitatif, suatu metode yang bertujuan untuk menguji teori-teori tertentu dengan cara meneliti antar variabel. Variabelvariabel ini akan diukur sehingga data yang terdiri angka-angka dapat dianalisis berdasarkan prosedur-prosedur statistik. Dalam penelitian ini samplenya adalah siswa kelas XII yang berkeluarga single parent terlihat pada tabel berikut ini:

\section{Tabel $\quad 3.2$}

Sample Penelitian

\begin{tabular}{|c|c|c|c|c|}
\hline No & Kelas & $\begin{array}{c}\text { Laki- } \\
\text { laki }\end{array}$ & Perempuan & Jumlah \\
\hline 1 & XII & 170 & 82 & 252 \\
\hline Total & 1 & 170 & 82 & 252 \\
\hline
\end{tabular}

\section{HASIL}

Berdasarkan hasil interprestasi data menunjukkan bahwa, penelitian ini membuktikan antara keluarga single parent dengan kemandirian belajar siswa di SMA Negeri 2 Padangsidimpuan terdapat korelasi positif yang signifikan dengan kriteria korelasi sedang, adapun kriteria korelasi adalah sebagai berikut:
a. $\quad 0,00-0,0199$ : sangat rendah
b. 0,20 - 0,399: rendah
c. $0,40-0,599$ : sedang
d. 0,60 - 0,799 : kuat
e. $0,80-1,000$ : sangat kuat

Besar korelasi antara keluarga single parent dengan kemandirian diperoleh sebesar $41,3 \%$ sedangkan $58,7 \%$ merupakan besar korelasi dari faktor lain yang tidak diteliti dalam penelitian ini. Berdasarkan pengaruh variabel lain disebut juga sebagai error (e). Dalam menghitung nilai error tersebut dapat menggunaan rumus $e=1 R 2$. Besarnya nilai koefisien determinasi atau $\mathrm{R}$ Square ini umumnya berkisar antara 0-1. Dengan demikian, jika dalam sebuah penelitian di temui $\mathrm{R}$ Square bernilai minus atau negative (-), maka dapat dikatakan bahwa tidak berpengaruh variabel $\mathrm{X}$ terhadap variabel $\mathrm{Y}$. Selanjutnya, semakin kecil nilai koefisien determinasi ( $R$ Square), maka ini artinya pengaruh variabel bebas (X) terhadap variabel terkait (Y) semakin lemah. Sebaliknya jika R Square semakin mendekati angka 1 maka pengaruh tersebut akan semakin kuat.

Pada penelitian ini menunjukkan bahwa hasil perhitungan statistik dengan menggunakan analisis korelasi product moment membuktikan bahwa "terdapat hubungan positif 
yang signifikan antara keluarga single parent dengan kemandirian belajar siswa di SMA Negeri 2 Padangsidimpuan dengan korelasi sedang". Jika dilihat dari koefisien korelasi setiap dimensi atau aspek pada dimensi single parent terdapat hubungan yang signifikan dengan kemandirian yaitu pada aspek time based conflict, strain based contect, behavior based conflict. Pada aspek kemandirian terdapat hubungan yang signifikan terhadap keluarga single parent, ini bisa dilihat dari aspek bebas, progresif dan ulet, inisiatif, pengendalian diri dan kemantapan diri.

Pada pengujian normalitas signifikan Asyimp.Sig (2-tailed) sebesar 0,200. Dalam pengambilan keputusan dalam uji normalitas klomogorov-smirnov yaitu apabila nilai signifikan $\mathrm{p}>0,05$ maka distribusi data tersebut normal. Maka dari itu skor variabel single parent dengan kemandirian itu normal.

Hipotesis yang menunjukkan Sig. 0,033 $<0,05$ ada hubungan antara keluarga single parent dengan kemandirian belajar siswa di SMA Negeri 2 Padangsidimpuan diterima, dengan kata lain siswa yang memiliki keluarga yang single parent akan berpengaruh terhadap kemandirian belajar siswa. Pengujian ini dilakukan dengan menggunakan program SPSS 22 for windows. Siswa yang memiliki keluarga yang single parent akan memengaruhi dirinya untuk lebih mandiri dalam segala hal baik dalam hal mengendalikan diri,bertanggung jawab, mengambil keputusan, mengatasi masalah sendiri, inisiatif dan progresif. Dalam hal kemandirian seorang siswa juga dapat lihat dari bagaimana siswa berperilaku disekolah dan bagaimana cara siswa itu akan bergaul dengan teman-temannya. Hubungan antara siswa dengan keluarga terutama ayah dan ibunya akan mempengaruhi bagaimana siswa berperilaku. Menjadi orang tua bukanlah hal yang mudah karena banyak tugas-tugas yang harus dilakukan terutama dalam membesarkan anak. Keutuhan dalam keluarga sangat dibutuhkan untuk membantu dalam perkembangan diri anak dan mendapatkan kasih sayang yang utuh dalam sebuah keluarga.

Dalam sebuah keluarga terdapat fungsi masing-masing anggota keluarga meskipun salah satu dari orangtua dalam keluarga tidak ada, tetapi keluarga yang tinggal harus tetap memenuhi kebutuhan dan fungsi-fungsi yang diperlukan oleh sebuah keluarga, sehingga meskipun hanya dengan satu orangtua keberfungsian keluarga masih terjaga. Setiap anak membutuhkan perhatian dan kasih sayang, tidak dapat dipungkiri bahwa anak mendapatkan dampak psikologis yang dapat berpengaruh pada perilaku anak di rumah, sekolah maupun dalam masyarakat. Adanya perbedaan dalam struktur keluarga memberikan efek yang tidak dapat dihindari. Dengan kasih sayang dan perhatian yang diberikan kepada anak maka orang tua yang single parent akan mengatasi masalah mental anak, dia akan merasakan kembali keutuhan dalam keluarga. Sebagai orangtua single parent memiliki tugas dalam mengembalikan kepercayaan, menumbuhkan kenyamanan dan dukungan sosial maupun emosional. 


\section{SIMPULAN}

Berdasarkan data hasil penelitian yang telah dilakukan dengan menganalisis statistik dan uji hipotesis penelitian yang berjudul hubungan keluarga single parent dengan kemandirian belajar siswa di SMA Negeri 2 Padangsidimpuan dapat disimpulkan bahwa ada hubungan yang signifikan antara keluarga single parent dengan kemandirian belajar siswa di SMA Negeri 2 Padangsidimpuan. Berdasarkan hasil analisis diatas maka diperoleh nilai $r$ hitung adalah 0,413 sedangkan $r$ tabel taraf signifikan $0,05=0,361$, jadi nilai $r$ hitung lebih besar dari $\mathrm{r}$ tabel yaitu $0,413>$ 0,361 . Besar korelasi antara keluarga single parent dengan kemandirian diperoleh sebesar $41,3 \%$ sedangkan $58,7 \%$ merupakan besar korelasi dari faktor lain yang tidak diteliti dalam penelitian ini.

Dengan demikian variabel $\mathrm{X}$ yaitu keluarga single parent dengan variabel $\mathrm{Y}$ kemandirian siswa adalah signifikan artinya ada hubungan keluarga single parent dengan kemandirian belajar siswa di SMA Negeri 2 Padangsidimpuan, dengan korelasi "sedang". Siswa yang memiliki keluarga yang single parent akan memengaruhi dirinya untuk lebih mandiri dalam segala hal baik dalam hal mengendalikan diri, bertanggungjawab, mengambil keputusan, mengatasi masalah sendiri, inisiatif dan progresif.
Arikunto. Suharsimi.2006. Prosedur Penelitian Suatu Pendekatan Praktik. Jakarta : Rineka Cipta

Azwar, S. 2015. Reliabilitas dan Validitas. Yogyakarta. Pustaka Belajar

A. Muri Y.2014. Metode Penelitian Kuantitatif, Kualitatif dan Penelitian Gabungan. Jakarta : Prenamedia Group

Listia Dewi. "Kehidupan Keluarga Single Parent". 2017, 2(3): hal 44-47

Masrun, Martaniah, Martono, Hilman,F., Wulan,R., Bawani,N.A.2006."Studi Mengenai Kemandirian pada Penduduk di Tiga Suku (Jawa, Batak, Bugis)". Laporan Penelitian. Yogyakarta, Kantor Menteri Negara dan Lingkungan Hidup : Fakultas Psikologi UGM

Nurfadilah.(2015). "Peran Ibu Single Parent dalam Menumbuhkan Kemandirian Anak di Desa Bojong Timur Magelang". Prodi pendidikan Pancasila dan Kewarganegaraan Fakultas Ilmu Sosial Universitas Negeri Semarang

Olatunde, Abisola.2010. Perilaku Agresif Remaja yang di Asuh Oleh Ibu Single Parent. Jurnal Sosiologi. Vol 3(1). Halaman 8 -9

Rika Sa'diyah (2017). "Penting Melatih Kemandirian Anak" Vol.XIV No.1 halaman : 137-38

Stanislaus,S.(2010). "Keterampilan Sosial Remaja yang Diasuh Secara Single Parent Akibat Penelantaran Rumah Tangga". Jurnal Psikologi Intuisi 2(1). Halaman 67

\section{DAFTAR RUJUKAN}


Suci Fadhla Hasanah, Ni'matuzahroh (2017). "Work Family Conflict pada Single Parent" Vol.1 No.2 hlm:385

Yusuf A Muri. 2013. Metode Penelitian

Kuantitatif, Kualitatif dan Penelitian

Gabungan. Padang. Halaman : 227 228

Zahrotul Layliyah. (2013) "Perjuangan

Hidup Single Parent". Jurnal

Sosiologi Islam, 3 (1): hal.90-92 